\title{
KARAKTERISTIK PERUBAHAN FUNGSI RUANG RUMAH SEDERHANA BERSUBSIDI (STUDI KASUS: PERMUKIMAN BSS 2- MONCONGLOE)
}

\author{
Marwati \\ Jurusan Teknik Arsitektur \\ Fakultas Sains dan Teknologi UIN Alauddin Makassar \\ Jl. Sultan Alauddin No. 63, Gowa, Sulawesi Selatan. 92113 \\ E-mail: marwati.adalle@uin-alauddin.ac.id
}

\begin{abstract}
Abstrak: Kebutuhan akan tempat tinggal merupakan hal yang esensial dalam perkembangan kehidupan manusia, termasuk penyediaan akomodasi bagi masyarakat menengah ke bawah dengan perumahan bersubsidi. Pembangunan perumahan bersubsidi secara simultan dan banyak terjadi di kawasan penyangga Kota Makassar, salah satunya di Kecamatan Moncongloe. Perubahan dan penambahan rumah inti terjadi dalam waktu kurang dari lima tahun sejak dibangun. Penguasaan ruang tambahan memerlukan pengawasan dari aspek fungsi dan kesehatan penghuninya. Penelitian ini bertujuan untuk mengetahui karakteristik perubahan posisi dan pola spasial pada periode pasca hunian. Lokasi penelitian berada di komplek perumahan Bumi Salam Sejahtera (BSS) 2 Kecamatan Moncongloe dengan menggunakan sampel rumah yang telah mengalami perubahan dipilih secara purposive. Data hasil observasi kemudian dianalisis secara deskriptif dengan membandingkan dengan denah rumah induk. Hasil penelitian menemukan bahwa perubahan lokasi terjadi pada ruang kamar mandi dan penambahan ruang tidur, usaha dan jemur. Penghuni perlu memperhatikan faktor pencahayaan dan sirkulasi udara yang baik pada pasca perubahan atau penambahan ruang pada rumah.
\end{abstract}

Kata Kunci: BSS, ruang serbaguna, rumah subsidi

\section{PENDAHULUAN}

$\mathrm{R}$ umah merupakan kebutuhan dasar manusia, di samping pendidikan dan kesehatan. Pemerintah berusaha dalam memenuhi kebutuhan rumah bagi masyarakat perkotaan dengan keadaan ekonomi menengah ke bawah adalah dikembangkannya rumah sederhana. Rumah berfungsi memberikan rasa aman serta perlindungan dari lingkungan sekitar (Wicaksono, 2009). Program realisasi 15.000 unit pada tahun 2017 yang diperuntukkan bagi segmen masyarakat berpenghasilan rendah atau MBR itu sebagian besar terkonsentrasi pada daerah penyangga Makassar dalam kerangka Kawasan Mamminasata (Rahmat, 2017). Adanya animo pengunjung terhadap rumah bersubsidi di REI Expo tergolong tinggi dan program pengadaan RSH ini akan terus dilakukan oleh pemerintah hingga kebutuhan akan perumahan bagi golongan menengah ke bawah terpenuhi (Kurnia, 2019). Program pembangunan rumah sehat bersubsidi (RSS) dibangun oleh Perum Perumnas di lingkungan Makassar, Maros dan Gowa. Program ini telah dimulai sejak tahun 2015 di Makassar dan sekitarnya. Konsep pembangunan rumah sederhana dalam bentuk deret di Makassar ini secara fenomena sepertinya cocok untuk dipakai sebagai strategi pemecahan masalah perumahan. Hal ini 
terlihat dengan banyaknya pembangunan rumah sederhana dalam bentuk deret secara simultan di Kawasan Makassar, Maros dan Gowa yaitu Kawasan Moncongloe. Program ini bertujuan untuk mewujudkan tersedianya rumah dengan jumlah yang memadahi di dalam lingkungan yang sehat, memenuhi syarat dan standar kesehatan, memberi kepuasan penghuni, kuat (tahan lama) dan terjangkau harganya. Bentuk rumah deret menjadi fenomena baru dalam pembangunan rumah sederhana dalam skala besar di Makassar, Maros dan Gowa.

Beberapa unitnya telah mengalami perubahan dalam waktu yang singkat dari segi fisik bangunan maupun bentuk bangunan. Penghuni melakukan penambahan ruang, perombakan ataupun pergantian material rumah inti (rumah yang dibuat oleh perumnas). Masa pasca huni ini terdapat beberapa kondisi yang mendukung maupun tidak yang ditimbulkan oleh program ini. Perubahan ini terjadi dalam waktu usia bangunan masih kategori baru (kurang dari 5 tahun). Perkembangan pembangunan perumahan RSS di Makassar saat ini belum sepenuhnya didasarkan pada keinginan dan aspirasi penghuni. Hal ini terlihat pada kondisi dan keadaan bangunan rumah pasca huni tersebut.

Beberapa penelitian pasca huni rumah tentang persepsi kepuasan penghuni terhadap rumah sederhana ini telah dilakukan. Murniati (2010) menemukan kondisi di mana pemberian subsidi KPR-RSH belum tepat sasaran, dan menyarankan ketepatan sasaran juga dipengaruhi oleh tiga faktor antara lain: tingkat penghasilan, jenis pekerjaan dan tingkat pendidikan. Preferensi konsumen yang tinggal di Perumahan Taman Palumbon Asri mereka sangat puas dengan lokasi, desain, kualitas bangunan, harga dan lingkungan (Anthony et al., 2018). Hal yang sama juga dikemukan oleh Samsuddin (2000) tentang kepuasan berdasarkan rumah sederhana dipengaruhi oleh tingkat pendapatan penghuni, faktor sosial budaya, status kepemilikan bangunan, keamanan lingkungan, kebersihan lingkungan, ketersediaannya fasilitas, ketersediaannya sarana dan prasrana, tipe rumah, dan pengelolaan oleh Perum Perumnas. Variabel dari faktor lokasi, faktor kualitas bangunan, dan faktor kelengkapan fasilitas dan infrastruktur memiliki pengaruh positif terhadap kepuasan penghuni perumahan bersubsidi di kota Malang (Caritas et al., 2017).

Penelitian tentang perkembangan kondisi fisik rumah sederhana pasca huni yang dilakukan oleh Devi (2004) menemukan bahwa secara umum persyaratan lokasi, persyaratan prasarana lingkungan sudah sesuai namun persyaratan teknis rumah, kekuatan dan keawetan struktur bangunan belum mencapai usia minimal yaitu 20 tahun. Menurut Wibowo (2003), rumah sederhana untuk lama tinggal di bawah 5 tahun faktor yang berpengaruh pada kondisi fisik rumah pasca huni adalah kualitas rumah, ketersediaan sarana dan prasarana dan lokasi. Terdapat beberapa bangunan yang telah dalam kondisi berubah menimbulkan efek perubahan pada elemen tampak bangunan secara tidak langsung maupun keseluruhan. Hal itu dapat terlihat pada beberapa elemenelemen tampak bangunan di antaranya: bentuk atap, material atap, bentuk pintu, bentuk jendela, ventilasi udara, ornamen, AC, landscape, teras, dan carport (Putra, 2018). Selain itu menurut Tam et al. (2017) dalam menjaga daya tahan perlu diperhatikan faktor perawatan pada material yang digunakan pada bangunan dan faktor cuaca (De Silva et al., 2012). Kualitas material rumah sederhana menurut Wardana (2004) dapat dilpengaruhi oleh cara pemeliharaan terhadap rumah.

Dengan demikian perlunya perhatian terhadap dampak perubahan pasca huni pada rumah sederhana karena masyarakat mengapresiasi program rumah sederhana ini dari aspek lokasi, desain, harga dan lingkungan. Fenomena perubahan kondisi fisik pada rumah sederhana ini membuat rumah inti mengalami degradasi yang tidak sesuai standar umur rumah yaitu 20 tahun masa pakai (Keputusan Menteri Permukiman dan Prasarana 
Wilayah No: 403/KPTS/M/2002, 2002). Pembagian tanggung jawab diperlukan dalam pengelolaan program pengadaan rumah sederhana ini antara pemerintah, swasta dan penghuni. Penyesuaian yang dilakukan oleh penghuni rumah sederhana sangat terbentuk oleh kemampuan mereka, terutama dalam hal pendanaan, sehingga jenis penyesuaian yang dilakukan termasuk pada adaptasi yang dititikberatkan pada penyesuaian terhadap kondisi rumah yang ada (Muchdar, 1989). Menurut Yudohusodo (1991) menguraikan beberapa cara untuk menekan harga rumah antara lain dengan penyederhanaan desain dan perancangan bangunan, penggunaan bahan bangunan yang murah dan penurunan kualitas pekerjaan finishing. Menurut Sastrisasmito (1997) menyatakan bahwa pemberian standar yang sangat minim pada proyek pembangunan rumah sederhana ini cenderung menciptakan kekumuhan, karena penyediaan standard dan kualitas sarana dan prasarana yang tidak bertanggung jawab, melainkan hanya sebagai generalisasi produk sebagai program pemerintah dalam penyediaan perumahan bagi golongan masyarakat rendah. Hal ini sesuai dengan pendapat Turner (1831) bahwa proses pembangunan pada tahap akhir ini mempunyai jangka waktu paling lama yang terdiri dari kegiatan penghuni, pemeliharaan dan kelangsungan hidup beserta keluarga dengan aman dan penelitian dapat dilakukan secara bertahap sesuai dengan perkembangannya (Schen, 2007). Fenomena perubahan bentuk rumah sederhana yang terjadi pada masa pasca huni akan memengaruhi keberlanjutan sebuah program/rumah.

Kajian preferensi penghuni terhadap desain, lokasi, perubahan fungsi ruang, kualitas material, sarana, partisipasi penghuni sepertinya belum cukup. Kajian tentang perubahan struktur belum dilakukan pada rumah sederhana pasca huni. Hal ini sesuai dengan teori Gasperz (1997) yang menjelaskan bahwa tingkat kelayakan produk (rumah) yang diharapkan untuk tercapainya kepuasan konsumen jangka panjang dengan tujuh faktor yang berpengaruh. Kemampuan beradaptasi mengacu pada kapasitas bangunan untuk mengakomodasi perubahan besar. Pada kenyataannya, perubahan tidak dapat dihindari, baik di lingkungan sosial, ekonomi dan fisik, dan dalam kebutuhan dan harapan penghuni. Adaptasi dan fleksibilitas telah memainkan peran penting dalam proyek arsitektur eksperimental di era Industri (Ismail \& Rahim, 2011)

Bagi sebagian orang, rumah sehat cukup dipel, disapu dan banyak tanamannya. Padahal kondisi tersebut tidak menjamin sebuah konsep rumah sehat. Menurut Wicaksono (2009), rumah sehat harus secara psikologis maupun fisiologis. Sebuah rumah dikatakan sehat apabila perabot diatur dan dikelompokkan berdasarkan fungsinya, ventilasi dan pencahayaan yang cukup, serta pemilihan material yang aman bagi kesehatan. Akibat kurangnya pemahaman tentang manajemen ruang, penghuni rumah akan merasa kurang nyaman dalam beraktivitas, banyak waktu akan terbuang, stress dan lain sebagainya. Faktor yang memengaruhi kesehatan rumah antara lain: lay-out atau tata letak pengaturan ruangan; penggunaan material atau bahan bangunan; bentuk massa bangunan, fasad dan struktur; barang yang tersimpan dalam rumah; dan faktor dari dalam atau luar rumah.

Dengan adanya fenomena pembangunan rumah sederhana dalam jumlah banyak dan perubahan bentuk yang terjadi pada rumah sederhana maka desain rumah yang ada perlu dikaji kembali, salah satunya konsep desain tata dan fungsi ruang bangunan sederhana sejak awal perlu dipertimbangkan agar masa pasca huni lebih efektif dan efisien terutama dalam hal biaya perubahan (Durability). Dalam melakukan perubahan, penghuni kemungkinan akan menghilangkan struktur yang sudah ada dan membuatnya kembali sesuai kebutuhannya (Performance). Oleh karena biaya struktur yang dihilangkan itu akan menjadi pertimbangan dalam mendesain tipe hunian selanjutnya. 
Perencanaan ruang yang sesuai kebutuhan fungsi ruang penghuni diharapkan menjadi salah satu alat kontrol dalam perubahan bentuk rumah sederhana. Dengan demikian perlunya kajian perubahan pola ruang yang terdapat pada rumah sederhana pasca huni dari aspek perubahan bentuk rumah dan zona kapling. Hal ini mendasari peneliti untuk mengetahui perubahan rumah sederhana pada masa pasca huni yang ditinjau perubahan ruang, perubahan pola struktur pada dengan lokasi studi pada rumah sederhana di Makassar dan sekitarnya. Kebutuhan ruang minimal menurut perhitungan dengan ukuran standar minimal adalah $9 \mathrm{~m}^{2}$, atau standar ambang dengan angka $7,2 \mathrm{~m}^{2}$ per orang. Sebagai konsepsi dasar kedua perhitungan tersebut masih digunakan dengan tetap mempertimbangkan bentuk akhir rumah pasca pengembangan (Permukiman, 2002). Dengan mengetahui perubahan fungsi ruang yang terjadi pada rumah sederhana pasca huni maka diharapkan dapat menjadi sebuah konsep bagi tipe selanjutnya yang sesuai dengan keinginan penghuni.

\section{METODE PENELITIAN}

Penelitian ini merupakan penelitian kualitatif dengan metode observasi dalam pengumpulan data dan analisis desktiptif yang menggunakan penjelasan data berupa kondisi objek penelitian yang telah diperoleh melalui hasil survei lapangan, yaitu pengamatan langsung dan wawancara. Kemudian melakukan analisis terhadap data yang sudah diperoleh untuk mencapai tujuan. Selain itu dalam meneliti dibutuhkan cara dengan mengumpulkan data yang berasal dari naskah wawancara, catatan lapangan, foto, dan dokumen resmi lainnya. Penelitian ini mengfokuskan pada perubahan fungsi ruang rumah tinggal pada perumahan sederhana bersubsidi dengan model rumah berderet. Lokasi studi berada pada perumahan sederhana Bumi Salam Sejahtera (BSS) di Kawasan Kecamatan Moncongloe (Gambar 1). Perumahan BSS yang mulai banyak mengalami perubahan bentuk yaitu pada BSS 2 .

Metode pengumpulan data merupakan hal yang sangat penting, karena untuk mendapatkan data di lapangan diperlukan metode yang tepat sehingga data yang diperoleh menjadi jelas dan akurat. Metode pengumpulan data yang digunakan pada penelitian ini adalah sebagai berikut:

1. Survei data primer, metode pengumpulan data dilakukan dengan observasi, pengambilan foto atau gambar, dan melakukan wawancara tidak terstruktur. Informan yang diwawancarai yaitu: a) Developer sebagai pihak pengembang untuk mendapatkan data dan gambaran lokasi penelitian; dan b) Pemilik rumah atau penghuni untuk mengetahui perubahan fungsi ruang yang dilakukan.

2. Survei data sekunder, data sekunder disini yaitu dengan mengumpulkan data-data dari studi literatur. Pengumpulan data tersebut dengan cara mencari literatur yang berkenaan dengan studi permasalahan yang diangkat. Data tersebut diperoleh melalui buku, jurnal, dan dokumen dokumen resmi yang dikeluarkan oleh pihak terkait.

3. Analisis data merupakan upaya untuk mencari dan menata secara sistematis catatan hasil observasi, wawancara, penggambaran, sketsa dan lainnya untuk meningkatkan pemahaman peneliti tentang kasus yang diteliti dan menyajikan temuannya bagi orang lain. Berdasarkan hasil kegiatan yang dilakukan, baik berdasar studi pustaka maupun studi lapangan.

4. Selanjutnya data yang terkumpul, dikategorisasikan, ditata urutan penelaahannya. Data yang diperoleh yang kemudian dianalisis dan disajikan dalam bentuk teks atau penjelasan naratif maupun dalam bentuk tabel. Pemahaman terhadap analisis data akan dilengkapi dengan teknik permodelan $2 \mathrm{D}$ terkait dengan pola perubahan ruang. 


\section{HASIL DAN PEMBAHASAN}

\section{Tinjauan Lokasi Perumahan BSS Moncongloe}

Lokasi objek observasi berada di Dusun Tammu-Tammu, Desa Moncongloe Bulu, Kecamatan Moncongloe, Kabupaten Maros. Perumahan untuk masyarakat berpenghasilan rendah (MBR) ini dibangun sebanyak 450 unit dengan luas bangunan 36 $\mathrm{m}^{2}$ dengan luas kapling $72 \mathrm{~m}^{2}$. Pembangunan perumahan BSS dimulai sejak Januari 2016 dan ditargetkan rampung pada Desember 2017. Harga yang ditawarkan per unit sebesar Rp122.500.000 (Haryandaru, 2016). Perumahan Bumi Salam Sejahtera 2 yang dikembangkan oleh PT. Sanusi Karsa Tama sebagai salah satu bentuk dukungan terhadap Program Sejuta Rumah. Lokasi rumah yang dijadikan objek studi berada pada perumahan BSS 2 dengan lokasi dapat dilihat pada Gambar 1.

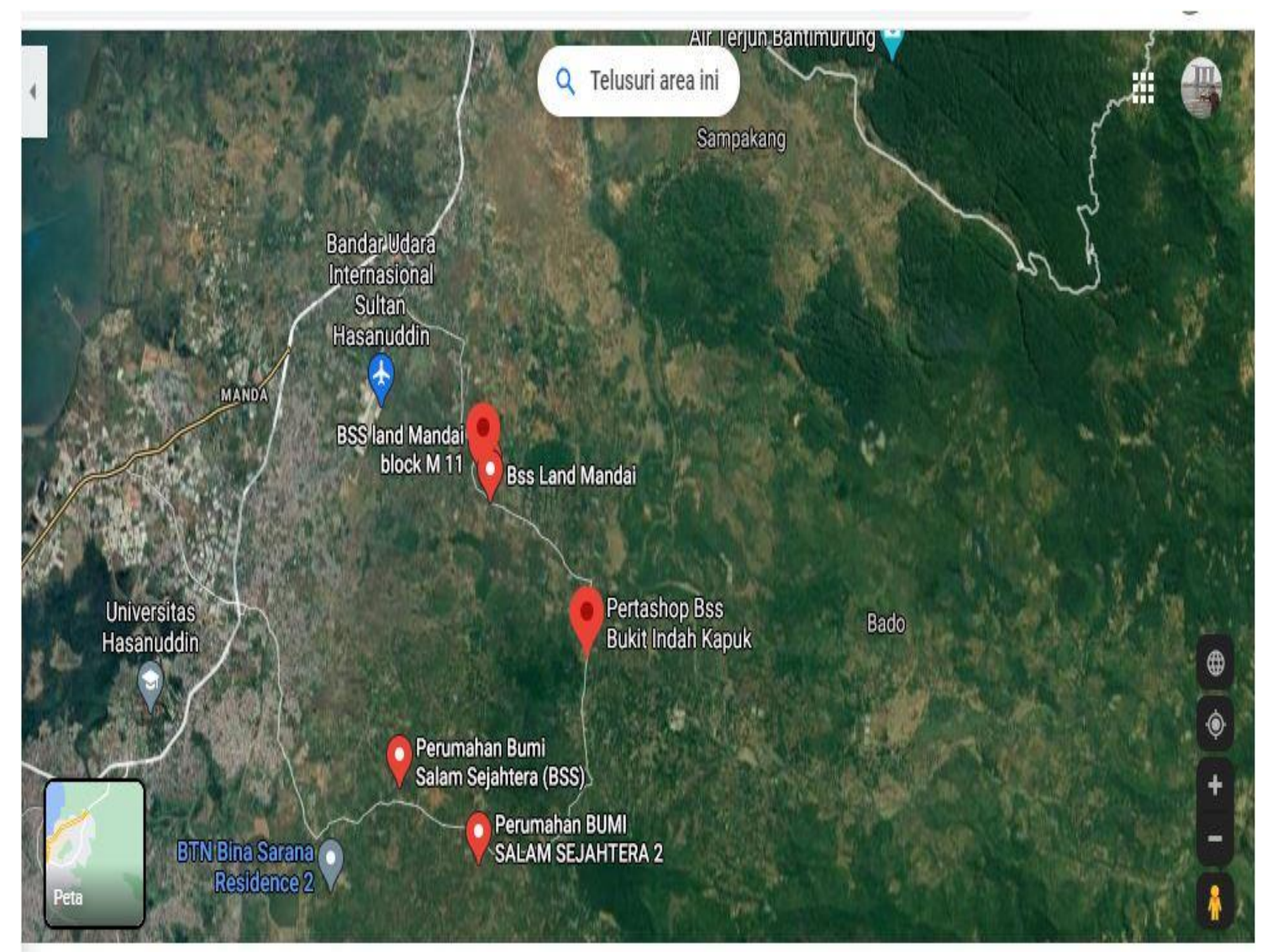

Gambar 1: Data foto citra Moncongloe (03 Maret 2021)

Sumber: https://earthexplorer.usgs.gov/, 2021 


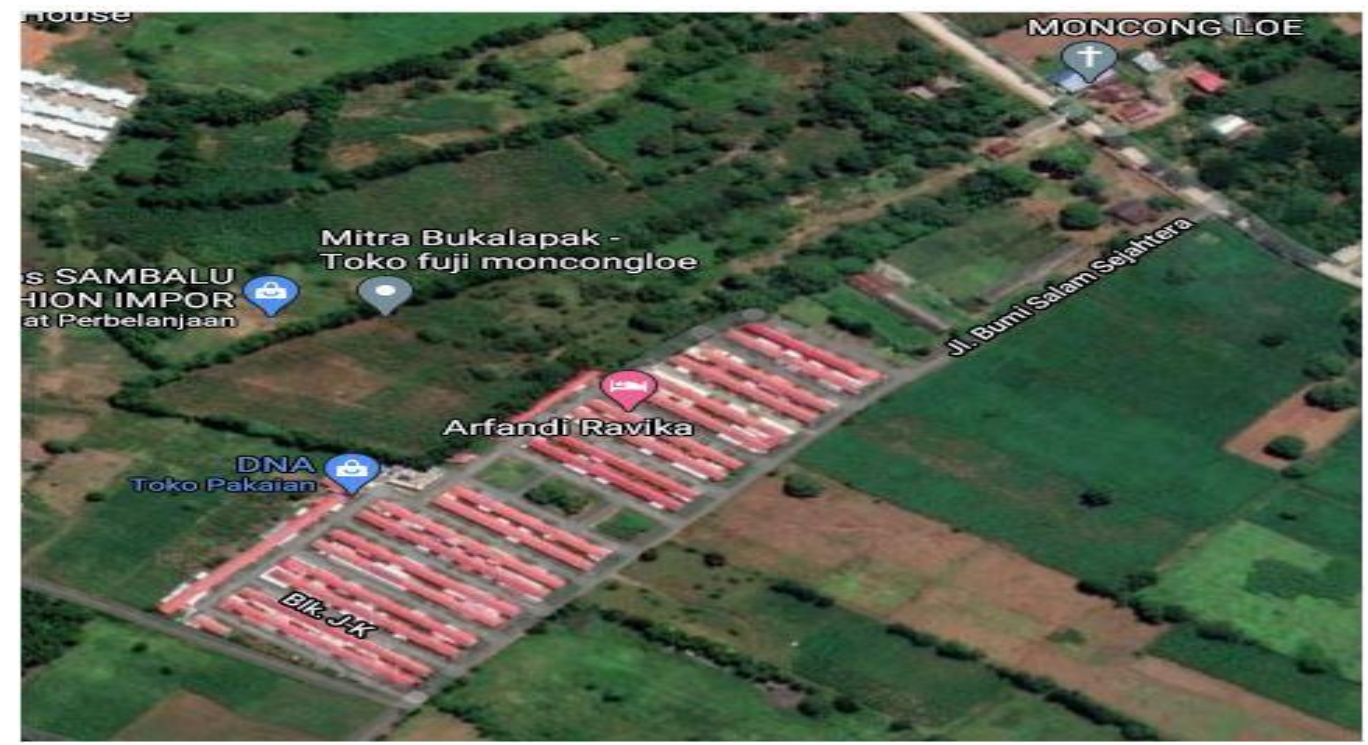

Gambar 2: Data foto citra BSS 2 (03 Maret 2021)

Sumber: https://earthexplorer.usgs.gov/, 2021

Lokasi Perumahan BSS 2 berada pada kawasan pengembangan kota yang disebut dengan Maminasata. Lokasi berada kurang lebih $6 \mathrm{~km}$ dari outer ring road. Akses dari Maros ke arah Gowa dan Makassar melewati jalur poros perumahan ini. Site plan perumahan BSS dan lokasi rumah yang dijadikan objek studi dapat dilihat pada Gambar 3.

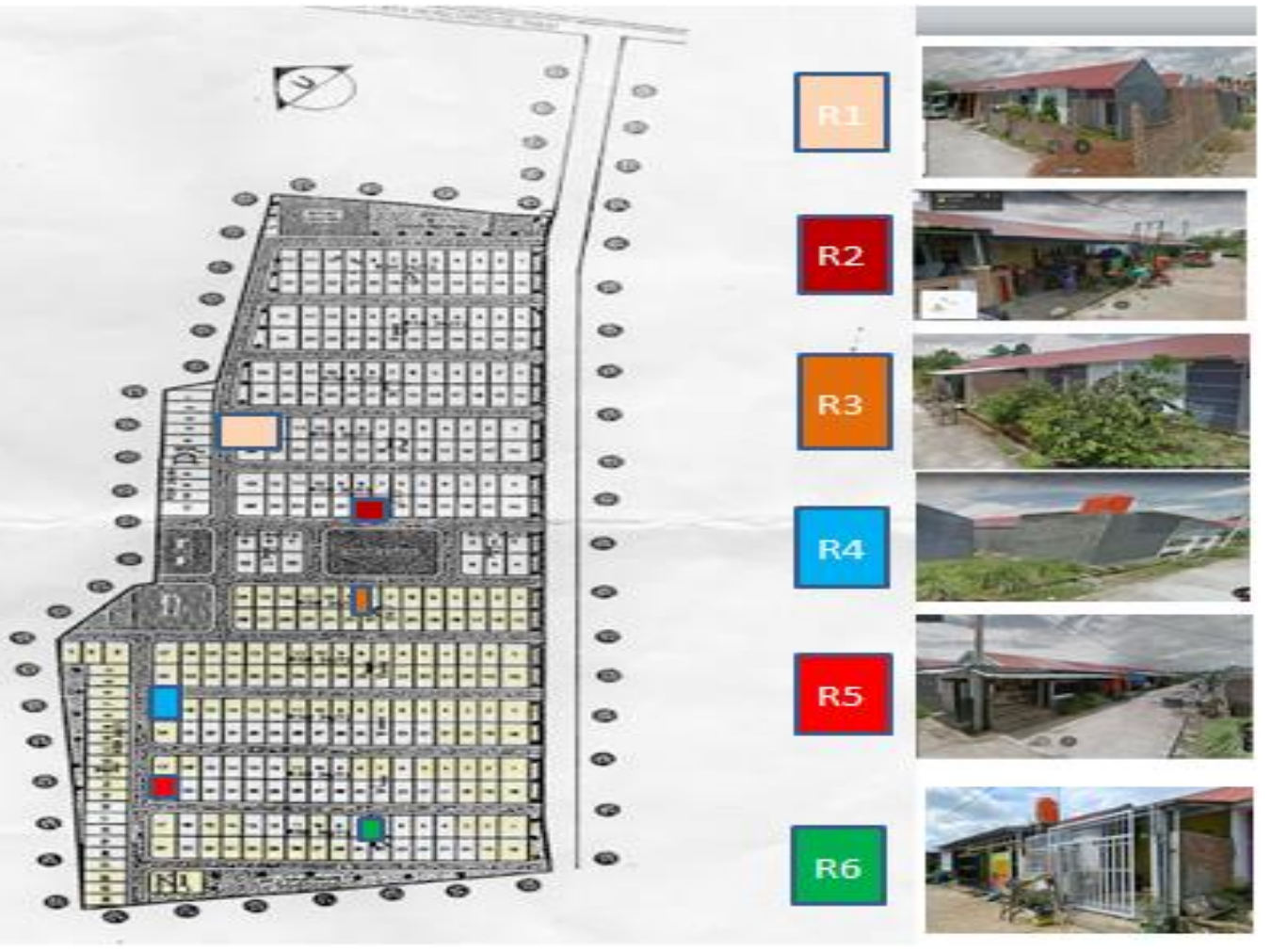

Gambar 3: Data lokasi objek studi

Sumber: Survei 2021 
Berdasarkan Gambar 3 diketahui bahwa dari beberapa objek rumah yang dijadikan studi kasus, terlihat bahwa perubahan mulai terjadi pada usia rumah kurang dari 5 tahun. Perubahan sepertinya terjadi pada sisi depan dan belakang rumah

\section{Kondisi Denah Awal Rumah}

Sesuai peraturan Menteri Permukiman dan Prasarana Wilayah (2002), kebutuhan ruang per orang dihitung berdasarkan aktivitas dasar manusia di dalam rumah. Aktivitas seseorang atau penghuni tersebut meliputi aktivitas tidur, makan, kerja, duduk, mandi, kakus, cuci dan masak serta ruang gerak lainnya. Dari hasil kajian, kebutuhan ruang per orang adalah $9 \mathrm{~m}^{2}$ dengan perhitungan ketinggian rata-rata langit-langit adalah 2,80 $\mathrm{m}$. Pola denah dan besaran ruang pada rumah yang menjadi objek studi dapat dilihat pada Gambar 4.
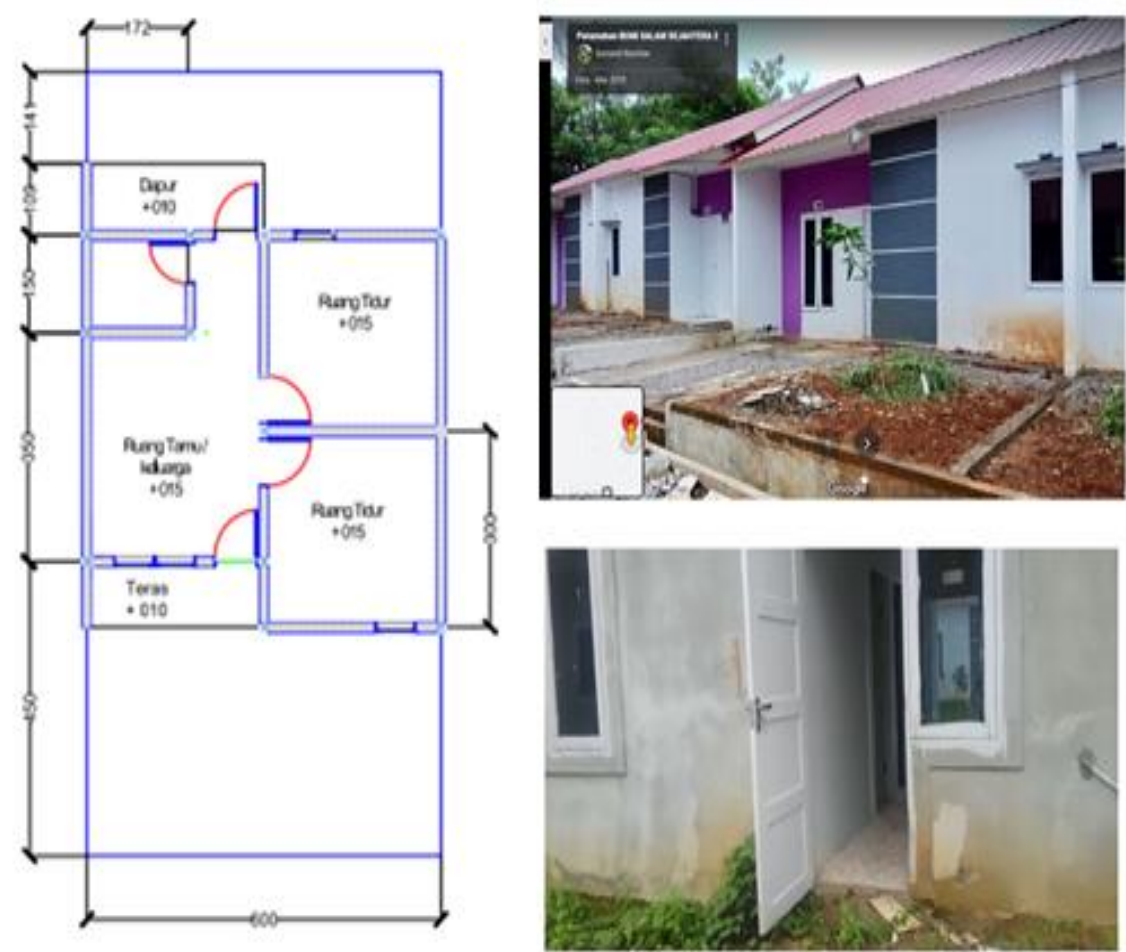

Gambar 4: Data denah awal tipe 36/72 dan foto citra BSS (03 Maret 2021) Sumber: Olah Data Primer, 2021 dan https://earthexplorer.usgs.gov/, 2021

Berdasarkan Gambar 4, besaran ruang untuk tamu $=9 \mathrm{~m}^{2}$; ruang tidur $9 \mathrm{~m}^{2} ; \mathrm{km} / \mathrm{wc}$ 2,6 $\mathrm{m}^{2}$ dan dapur terbuka yang terletak di belakang rumah. Pada gambar tersebut terlihat sisi depan terdapat ruang garasi dan taman dan di sisi belakang terdapat halaman belakang yang masih berupa lahan kosong.

\section{Kondisi Perubahan Fungsi Rumah}

Berdasarkan observasi pada objek rumah sederhana bersubsidi yang telah melakukan perubahan/penambahan pada rumah awal BSS, diperoleh data perubahan pada Tabel 1. 
Tabel 1. Kondisi perubahan fungsi ruang pada objek studi

Objek Kondisi perubahan \begin{tabular}{c}
$\begin{array}{c}\text { Fungsi ruang } \\
\text { tambahan/ } \\
\text { berubah }\end{array}$ \\
\hline
\end{tabular}

R1

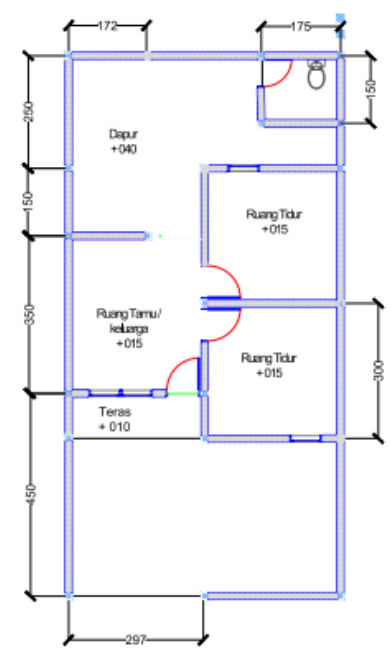

$\mathbf{R 2}$

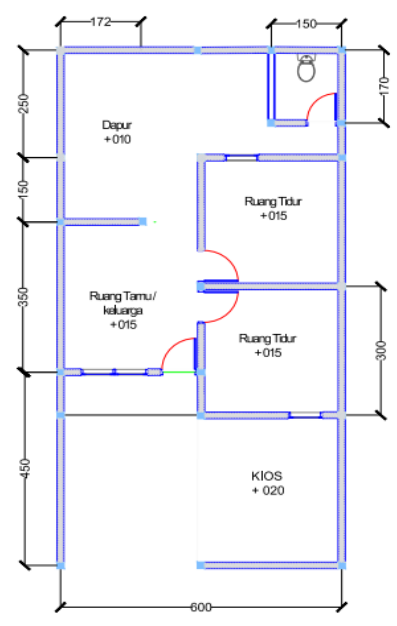

$\mathbf{R 3}$

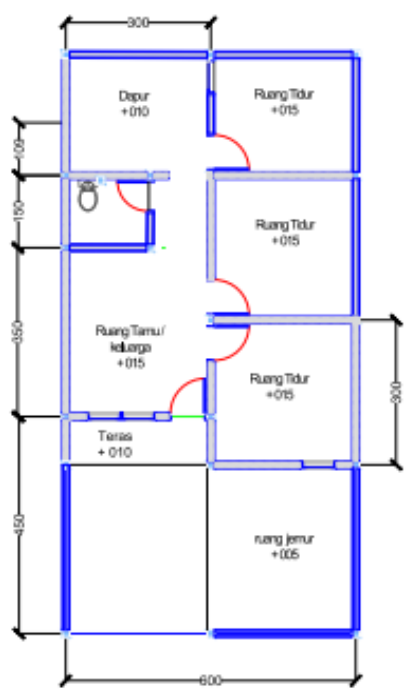

- Dapur

- $\mathrm{KM} / \mathrm{WC}$ lama dibongkar dan dibuat baru dan letaknya dipindahkan di sisi kanan belakang rumah

- $\mathrm{KM} / \mathrm{WC}$

- Sisi halaman belakang rumah dibangun menjadi ruang dapur

- Terdapat tendon air di atas KM/WC

- $\mathrm{KM} / \mathrm{WC}$ lama dibongkar dan dibuat baru dan letaknya dipindahkan di sisi kanan belakang rumah

- Dapur

- KM/WC

- Tempat usaha

- Sisi halaman belakang rumah dibangun menjadi ruang dapur

- Sisi depan terdapat ruang usaha
- Terdapat tambahan ruang cuci dan jemur pada sisi kiri depan rumah

- Dapur

- Ruang tidur

- Ruang jemur
- Pada sisi belakang dibuat tambahan ruang tidur dan dapur yang diperluas 
R4

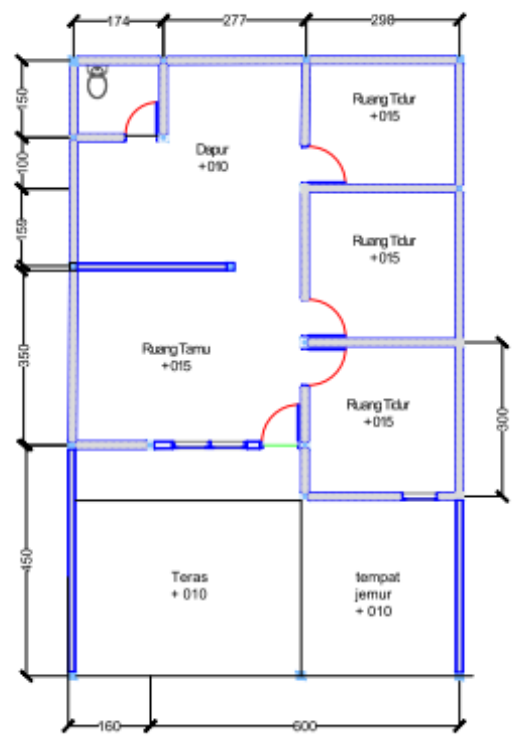

R5

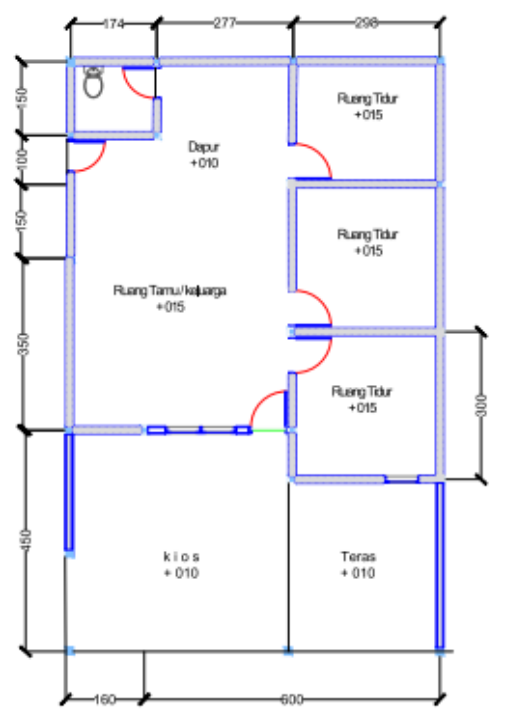

R6

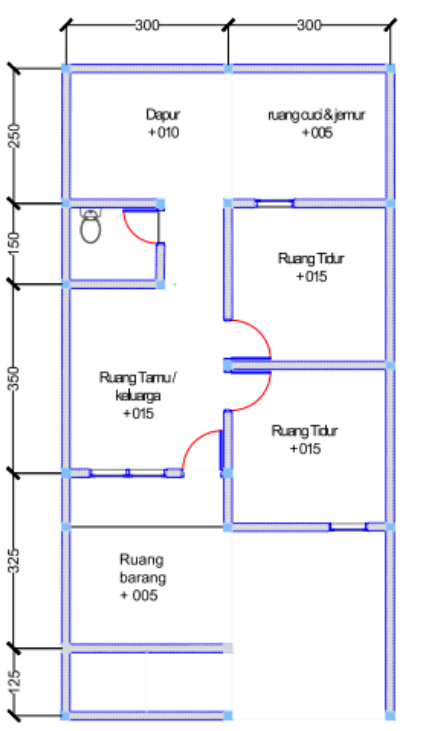

- Dapur

- $\mathrm{KM} / \mathrm{WC}$

- Ruang tidur

- Ruang jemur

- Dapur

- $\mathrm{KM} / \mathrm{WC}$

- Ruang tidur

- Ruang usaha

- Dapur

- Ruang jemur/cuci

- Tempat barang/gudang sementara
- Letak kapling sudut maka ada kelebihan tanah

- Km dibongkar kemudian dibuat baru yang letaknya dibelakang krn terdapat tendon air diatasnya

- Ruang tidur ditambah

- Ruang jemur pindah di sisi depan

- Letak kapling sudut maka ada kelebihan tanah dan terdapat pintu samping

- KM dibongkar kemudian dibuat baru yang letaknya dibelakang karena terdapat tandon air di atasnya

- Ruang tidur ditambah

- Ruang usaha terbuka dari arah depan dan samping

- Terdapat tambahan ruang cuci dan jemur pada sisi kanan belakang rumah

- Pada sisi depan terdapat gudang sementara dan tendon air diletakkan di sisi depan kiri rumah 
Karakter perubahan letak KM/WC pada sisi belakang rumah membuat ruang tengah menjadi lebih luas. Kebutuhan akan ruang makan yang privacy dan dapur yang lebih luas membuat pemilik rumah mengubah letak KM/WCnya. Penambahan ruang juga terlihat pada ruang tidur dan ruang usaha yang letaknya berada sisi depan.

\section{Analisis Perubahan Berdasarkan Teori}

Perubahan fungsi atau letak ruang pada rumah inti di lokasi studi jika dikaitkan dengan teori yang mendukung aktivitas yang dilakukan penghuni dapat dilihat pada Tabel 2 .

Tabel 2. Analisis perubahan fungsi berdasarkan teori

\begin{tabular}{|c|c|c|}
\hline Objek & Teori yang Mendukung & Teori yang tidak mendukung \\
\hline R1; R3; R6 & $\begin{array}{l}\text { Hal ini sesuai dengan pendapat } \\
\text { Turner (1831) bahwa proses } \\
\text { pembangunan pada tahap akhir } \\
\text { ini mempunyai jangka waktu } \\
\text { paling lama yang terdiri dari } \\
\text { kegiatan penghuni, pemeliharaan } \\
\text { dan kelangsungan hidup beserta } \\
\text { keluarga dengan aman dan } \\
\text { penelitian dapat dilakukan secara } \\
\text { bertahap sesuai dengan } \\
\text { perkembangannya (Schen, } \\
\text { 2007). }\end{array}$ & $\begin{array}{l}\text { Rumah tidak akan sehat jika } \\
\text { tidak memperhatikan sirkulasi } \\
\text { udara yang mengalir secara } \\
\text { alamiah (Wicaksono, 2009). } \\
\text { Dengan pola perubahan R1 } \\
\text { membuat sirkulasi udara hanya } \\
\text { satu arah dari luar ke dalam saja, } \\
\text { tidak ada sirkulasi balik, } \\
\text { sehingga ketika didapur terasa } \\
\text { panas. }\end{array}$ \\
\hline R2; R4;R5 & $\begin{array}{l}\text { Pendapat Turner; Schen; } \\
\text { Muchdar dan Gasperz } \\
\text { mendukung aktivitas yang } \\
\text { dilakukan oleh penghuni dengan } \\
\text { menambah ruang dan usaha } \\
\text { sebagai aktivitas hunian jangka } \\
\text { panjang. Aktivitas penambahan } \\
\text { ruang dilakukan melihat luasan } \\
\text { tapak yang tersedia. }\end{array}$ & $\begin{array}{l}\text { Masalah sirkulasi udara mulai } \\
\text { dari dapur dan KM kurang } \\
\text { efektif (Wicaksono, 2009). }\end{array}$ \\
\hline
\end{tabular}

Penambahan ruang yang dilakukan penghuni berdasarkan kebutuhan yang terjadi ketika penghuni berkembang baik secara ekonomi atau penambahan anggota keluarga. Hal ini terlihat adanya kebutuhan akan luasan ruang dapur yang lebih dari awalnya dan fungsi ruang makan bersatu dengan dapur. Adanya ruang usaha pada bagian depan rumah menggambarkan kebutuhan ruang usaha pada unit rumah sederhana karena lingkungan /lokasi perumahan jauh dari pasar atau pusat perbelanjaan. Ketidaktersediaannya tendon air pada rumah inti sehinga pada perkembangannya penghuni membuat atau menempatkan tendon sesuai keinginannya ada yang letaknya di depan dan di belakang. Kebutuhan ruang jemur juga tidak terlalu diperhatikan penghuni yang menggunakan ruang teras atau menjemur dijalan ketika cuaca panas.

Perubahan atau penambahan ruang pada rumah inti pada lokasi studi menggambar akan adanya kebutuhan namun perlu sirkulasi udara dan pencahayaan dalam ruang perlu diperhatikan agar keberlangsungan hidup penghuni lebih sehat yang sesuai dengan pendapat Turner (1831) dan Wicaksono(2009). Adaptasi penghuni telah memainkan peran penting dalam proyek arsitektur rumah sederhana (Ismail \& Rahim, 2011) dalam menggambarkan kebutuhan ruang. Sepertinya penghuni tidak memperhatikan kesehatan 
rumah yang terlihat proses penambahan rumah hanya berdasarkan kebutuhan dan kemampuan pembiayaan.

\section{KESIMPULAN}

Karakter perubahan fungsi ruang terdapat pada letak ruang kamar mandi yang sebagian besar bergeser dan terdapat tambahan ruang tidur, ruang tandon dan usaha. Penambahan luasan ruang mengikuti luas tapak yang tersedia namun sirkulasi udara dan pencahayaan masih perlu diperhatikan oleh penghuni ketika melakukan perubahan letak ruang. Perlunya desain rumah sederhana yang mengikuti kebutuhan penghuni dengan memperhatikan faktor kesehatan rumah.

\section{DAFTAR PUSTAKA}

Anthony, B., Tresani, N., \& Halim, R. P. (2018). Preferensi konsumen terhadap faktor-faktor penentu kepuasan konsumen dalam pengambilan keputusan pembelian perumahan bersubsidi di Karawang. Jurnal Muara Sains, Teknologi, Kedokteran dan Ilmu Kesehatan, 1(2), 159-168.

Caritas, A. I. A., Wisnumurti, W., \& Suharyanto, A. (2017). Faktor-faktor yang mempengaruhi tingkat kepuasan hunian perumahan bersubsidi di Kota Malang. Rekayasa Sipil, 11(1), 41-48. https://doi.org/10.21776/ub.rekayasasipil.2017.011.01.6.

De Silva, N., Ranasinghe, M., \& de Silva, C. R. (2012). Risk factors affecting building maintenance under tropical conditions. Journal of Financial Management of Property and Construction, 17(3), 235252. https://doi.org/10.1108/13664381211274353.

Devi., S. M. (2004). Perubahan Kualitas Hunian dan Lingkungan Perumahan Sangat Sederhana di Kota Balikpapan. [Skripsi]. Makassar: Universitas Hasanuddin.

Dipa Haryandaru. (2016). Perumahan BSS 2 (Sulawesi Selatan). Rei.or.Id. Retrieved from https://www.rei.or.id/newrei/berita-perumahan-bumi-salam-sejahtera-2-sulawesi-selatan.html\#.

Gasperz, V. (1997). Manajemen Kualitas Dalam Industri Jasa. Jakarta: PT. Gramedia.

Gray, T. R., \& Turner, N. (1831). The Confessions of Nat Turner. United State: Random House.

Ismail, Z., \& Rahim, A. A. (2011). Adaptability and Modularity in Housing: a Case Study of Raines Court and Next21. Malaysia: International Islamic University Malaysia.

Keputusan Menteri Permukiman dan Prasarana Wilayah No: 403/KPTS/M/2002. Pedoman Teknis Pembangunan Rumah Sehat (RSS) (2002).

Muchdar, U. (1989). Pemantauan Perkembangan Kualitas Lingkungan Perumahan. Bandung.

Murniati, H. (2010). Subsidi KPR-RSH Pada Perumahan Sudiang Permai, Makassar. Universitas Diponegoro.

Menteri Permukiman Dan Prasarana Wilayah. (2002). Keputusan Menteri Permukiman dan Prasarana Wilayah Nomor: 403/Kpts/M/2002 tentang Pedoman Teknis Pembangunan Rumah Sederhana Sehat (RS Sehat) Menteri Permukiman Dan Prasarana Wilayah.

Putra, R.P. (2018). Evaluasi Pasca Huni Tampak Depan Rumah Bersubsidi (Studi Kasus Perumahan Cikande Permai, Serang Banten). [Skripsi]. Jakarta: Universitas Mercu Buana Jakarta.

Rahmat, A. N. (2017). Seribu Rumah Subsidi Dibangun di Sulawesi Selatan. Bisnis. Com. Retrieved from https://ekonomi.bisnis.com/read/20170923/48/692304/seribu-rumah-subsidi-dibangun-disulawesi-selatan

Sastrosasmito, S. (1997). Konsep Kemitraan di dalam Pembangunan Perumahan: Suatu Telaah Deduktif. Manusia dan Lingkungan, 5.

Schen, M. S. (2007). Scientific reasoning skills development in the introductory biology courses for undergraduates. Retrieved from http://rave.ohiolink.edu/etdc/view?acc_num=osu1187063957.

Syamsuddin, M. (2000). Evaluasi Tingkat kepuasan Penghuni terhadap Fasilitas lingkungan Perumahan BTP Makassar. Makassar: Universitas Hasanuddin.

Tam, V. W. Y., Fung, I. W. H., \& Choi, R. C. M. (2017). Maintenance priority setting for private residential buildings in Hong Kong. Journal of Performance of Constructed Facilities, 31(3), 1-7. https://doi.org/10.1061/(ASCE)CF.1943-5509.0000988.

Tommy Kurnia. (2019). Program Rumah Subsidi Berlanjut, Ini Permintaan Pengembang. Liputan 6.Com. Retrieved from https:/www.liputan6.com/bisnis/read/4101938/program-rumah-subsidi-berlanjutini-permintaan-pengembang.

Wardana, A. (2004). Mengenal Bahan Bangunan Untuk Rumah. Ungaran: PT. Trubus Agriwidya.

Wibowo, B. R. (2003). Analisis pengaruh faktor kualitas produk, lokasi, desain bangunan, sarana dan 
313 Jurnal Teknosains, Volume 15, Nomor 3, September-Desember 2021, hlm. 302-313

prasarana terhadap kepuasan penghuni rumah sederhana tipe 36 di kawasan Sidoarjo Jawa Timur. Surabaya: Petra Christian University.

Wicaksono, A. (2009). Menciptakan rumah sehat. books.google.com. Retrieved from https://books.google.com/books?hl=en\&lr=\&id=AS-N9zVz8EsC\&oi=.

Wicaksono, A. A. (2009). KREASI :Tipe \& Solusi Menciptakan Rumah Sehat. Jakarta: Penebar Swadaya. Yudohusodo, S. (1991). Rumah untuk seluruh Rakyat. Jakarta: INKOPPOL, Unit Percetakan Bharakerta. 